\title{
WYBRANE ASPEKTY SPOLECZNEGO FUNKCJONOWANIA WYTWORÓW WIEDZY ARCHEOLOGICZNEJ I ARCHEOLOGII WE WSPÓLCZESNEJ POLSCE
}

\author{
SELECTED ASPECTS OF SOCIAL FUNCTIONING \\ OF PRODUCTS OF ARCHAEOLOGICAL KNOWLEDGE \\ AND ARCHAEOLOGY IN PRESENT-DAY POLAND
}

\author{
Michat Pawleta \\ Instytut Prahistorii, Uniwersytet im. Adama Mickiewicza \\ ul. Umultowska 89D, 61-614 Poznań, Poland \\ mpawleta@poczta.onet.pl
}

\begin{abstract}
In the article an attempt has been made to conceptualise the presence and range of the functioning of the products of archaeological knowledge, indirectly also archaeology, in social space in modern Poland, in the context of broader transformations of modern man's attitude towards the past. The ambition of the author has been to formulate certain regularities, observable in the processes of making prehistoric past present in modern times and to formulate specific developmental trends in this respect. The article describes the basic strategies of manifesting archaeological past, and shaping their trends, namely sensational attitude towards archaeological discoveries, reconstructionism, dramatisation of the past and its festivalisation. It also discusses the characteristic elements of the aforementioned trends, which create the specifics of the modern man's approach towards the past, including the prehistoric past.
\end{abstract}

KEY WORDS: manifestation of the past, archaeologial reconstrution and re-enactment, dramatisation of the past, sensuous experiencing of the past, commercialisation.

\section{WPROWADZENIE}

Artykuł ma na celu przedstawienie form i sposobów uobecniania przeszłości przez archeologów oraz społecznego funkcjonowania wytworów wiedzy archeologicznej, pośrednio zaś samej archeologii, we współczesnej Polsce. Zasygnalizowane w tytule zagadnienia ogólnie mieszczą się w polu badawczym określanym mianem „archeologia publiczna” (ang. public archaeology). Zajmuje się ona aktualnymi 
relacjami archeologów ze światem zewnętrznym, odnosząc się do problemów niemających związku z ich stricte naukową działalnością, lecz stanowiących skutek transmisji efektów tejże działalności do społeczeństwa (Deskur 2009, s. 286). W niniejszym artykule termin ,archeologia publiczna” proponuję więc rozumieć szeroko: jako wszelkie metody przedstawiania społeczeństwu osiągnięć archeologii, sposobów interpretowania przez nią przeszłości, a także wszelkich aktywności ukierunkowanych $\mathrm{w}$ stronę publicznego zrozumienia działalności archeologów oraz zaangażowania społeczeństwa $\mathrm{w}$ ich działania (Deskur 2009; Merriman 2004; Schadla-Hall 1999, 2006; Skeates, McDavid, Carman 2012). O ile poniższy tekst jedynie pobieżnie nakreśla problematykę, w żadnym stopniu nie pretendując do jej wyczerpania, o tyle zachowuje zamiar określenia pewnych prawidłowości zauważalnych we współczesnych procesach uobecniania archeologicznej przeszłości. Wychodzę w nim z podstawowego założenia, iż próba konceptualizacji przeszłości uobecnianej za pośrednictwem archeologii we współczesnym świecie jest niemożliwa bez odniesienia się do szerszego, teraźniejszego kontekstu kulturowego osoby badającej i/lub poznającej przeszłość.

Przedmiot badań archeologicznych może obejmować jedną z czterech domen: proces dziejowy, proces źródłotwórczy, proces badawczy (w tym proces źródłoznawczy) oraz proces społecznego obiegu wiedzy archeologicznej (Tabaczyński 1987, s. 13, 43-48; cyt. za: Zalewska 2014, s. 26); w artykule zajmuję się jedynie ostatnią z wymienionych. Biorąc pod uwagę cele poznawcze archeologii, tj. formułowanie rzeczowych wypowiedzi na temat przeszłej rzeczywistości, podejmowanie problematyki funkcjonowania archeologii i tworzonej przez nią wiedzy w przestrzeni społecznej, można uznać za bezproduktywne w takim sensie, iż nie wnoszą one niczego nowego do samej treści wiedzy na temat przeszłości. Ponadto dziedzina mająca za punkt odniesienia proces społecznego obiegu wiedzy archeologicznej jest trudna w konceptualizacji. Mimo że ze zjawiskiem obiegu wiedzy archeologicznej w społeczeństwie mamy do czynienia niemal od zarania archeologii, zagadnienia te nie stanowiły dotychczas - przynajmniej w archeologii polskiej - przedmiotu głębszej refleksji archeologów i równoprawnego w porównaniu z innymi polami eksploracji. Dopiero od niedawna stały się one istotnym elementem zainteresowania archeologów (np. Chowaniec 2010; Chowaniec, Więckowski 2012; Marciniak, Minta-Tworzowska, Pawleta 2011; Zalewska 2011, 2014). Płaszczyzna ta wydaje się jednak na tyle istotna, że warta jest zainteresowania oraz odrębnego namysłu. Odnosi się ona bowiem do najważniejszych dla współczesnej archeologii kwestii, dotyczących m.in. społecznego odbioru wytworów naukowej działalności archeologów, tego, że nie tylko archeolodzy interpretują przeszłość i kreują jej obrazy, że ich działalność poznawcza jest warunkowana/kreowana przez kontekst społeczno-kulturowy i jednocześnie kreuje ten kontekst, stanowiąc skuteczne narzędzie autokreacji archeologii (Mamzer 2004, s. 14; 2011, s. 34). 


\section{UOBECNIANIE PRZESZLOŚCI A STOSUNEK WSPÓŁCZESNEGO CZLOWIEKA DO PRZESZLOŚCI}

Jednym z podstawowych problemów archeologii jest uobecnianie przeszłości, do którego można się odnieść poprzez dwa powiązane ze sobą aspekty. Z jednej strony uobecnianie sugeruje problem nieobecności przeszłości. Skoro nie istnieją już społeczeństwa, które bada archeolog, to badacz sam - opierając się na pewnych znaleziskach, które po nich pozostały, jak również na określonych naukowych procedurach ich badania oraz interpretacji - tworzy przedmiot swego badania. $Z$ drugiej natomiast strony uobecnianie przeszłości oznacza „przywrócenie jej do życia” w teraźniejszości poprzez wydobycie na światło dzienne jej materialnych reliktów i tworzenie na ich podstawie narracji na temat przeszłości (Mamzer 1998, s. 299). Wskazuje to wyraźnie na konstruktywistyczny charakter wiedzy o przeszłości, a tym samym dużą wagę kontekstu teraźniejszości, w którym kreowane są wizerunki przeszłości i który determinuje ich kształt: „uobecnienie przeszłości to jej odsłonięcie, ujawnienie w teraźniejszości, czyli w nas samych w owej teraźniejszości usytuowanych. Przeszłość bowiem jako taka nie istnieje sama w sobie: istnieje tylko jako przeszłość dla nas" (Mamzer 1998, s. 304). Uobecnianie (prezentyfikacja) to zatem - pomijając pytania o aktualny status ontologiczny i epistemologiczny materialnych reliktów z przeszłości - przedstawianie we współczesności tego, co już nie jest obecne, czyli przeszłości, dzięki czemu staje się ona ponownie widzialna i namacalna.

Przeszłość, w tym przeszłość pradziejowa, ulega materializacji w procesach uprzedmiotowienia i uobecnienia, co ostatnio przypomniał choćby Arkadiusz Marciniak (2012, s. 162; 2013, s. 19). Uobecnianie przeszłości, jak zauważa dalej, przejawia się dzisiaj w dwóch podstawowych postaciach, mianowicie: w formach zintelektualizowanych, stanowiących naukową interpretację przeszłości, a także w doświadczanych bądź przeżywanych, czyli wszelkich próbach fizycznego kontaktu z przeszłością i namacalnego sprawdzenia, jak w rzeczywistości było bądź jak mogło być. Wskazuje on także, iż zróżnicowane wizerunki uobecnianej w przedmiotach przeszłości, które powstają na kilku wzajemnie uzupełniających się płaszczyznach oraz budowane są za pomocą różnych środków i mediów, przyjmują trzy podstawowe postaci: opisową (prace naukowe i popularnonaukowe), wizualną (ryciny, fotografie, rekonstrukcje) oraz doświadczaną (rekonstrukcje, odtwórstwo historyczne, eksperymenty archeologiczne). Ostatniemu z wymienionych aspektów uobecniania przeszłości towarzyszą bardziej emocje niż rozumowe podejście, wskutek czego współczesny człowiek ulega złudzeniu doświadczania przeszłości (Minta-Tworzowska 2009, s. 17; 2012, s. 147).

W rozważaniach na temat społecznego funkcjonowania wytworów wiedzy archeologicznej niezwykle istotny jest kontekst. Umożliwia on bowiem ukazanie zarówno zróżnicowanych uwarunkowań współcześnie kreowanych wizerunków przeszłości, jak również tego, że na uprawianie archeologii, będącej praktyką kultu- 
rową, a jednocześnie specyficznym podejściem do przeszłości i jej reliktów we współczesności, duży wpływ wywierają zachodzące obecnie w świecie procesy i zjawiska. Zmiany współczesnych postaw społecznych wobec przeszłości w Polsce można zaobserwować na przykładzie czterech powiązanych ze sobą elementów, mianowicie: (1) wzroście znaczenia pamięci w życiu publicznym; (2) prywatyzacji przeszłości, polegającej na tworzeniu jej zindywidualizowanych wizerunków; (3) przekonaniu współczesnego człowieka o możliwości uzyskania bezpośredniego wglądu w przeszłość poprzez jej zmysłowe doświadczanie; oraz (4) komercjalizacji (utowarowieniu) przeszłości i dziedzictwa kulturowego, związanej z przekształcaniem treści odnoszących się do przeszłości w produkty rynkowe pod postacią dóbr oraz usług (Kwiatkowski 2008, s. 39-40; 2009, s. 131-134). Z kolei Andrzej Szpociński (2005), piszący o współczesnej kulturze historycznej społeczeństwa polskiego, wskazuje na wykształcenie się nowej formy wrażliwości historycznej, dla której rysem charakterystycznym jest dążenie do bezpośredniego, autentycznego oraz zmysłowego doświadczania przeszłości. Przejawia się ona w dominacji takich form przeżywania przeszłości, w których główną rolę odgrywa nie intelekt, lecz zmysły. Manifestacją takiej tendencji jest m.in. pojawienie się różnego rodzaju inscenizacji, performansów, happeningów, spektakli rekonstrukcji historycznych, opowiadających o pewnych wydarzeniach z dziejów, które Autor określa zbiorczą nazwą widowisk przeszłości (zob. też Szpociński, 2007, 2010, 2012; Skórzyńska 2010). Również Barbara Szacka (2009) wskazuje na istotne przewartościowania w relacjach człowieka z przeszłością, które jej zdaniem są jednocześnie zmianami stosunku do przeszłości pojmowanej zarówno jako pamięci dziejów własnej zbiorowości (dotyczą one tego, co się pamięta), jak i przeszłości - jako tego, co było kiedyś (dotyczą tego, jak się pamięta). W pierwszym przypadku zaobserwowane zmiany polegają na spadku zainteresowania historią, skróceniu horyzontu czasowego, zainteresowaniu dziejami społeczności lokalnej oraz rodziny. Natomiast zmiany dotyczące tego, jak się pamięta, przejawiają się we wzroście indywidualistycznych postaw w ocenie postaci historycznych (indywidualizmu), skłonności do osobistego, zmysłowego i cielesnego przeżywania czy doświadczania przeszłości oraz komercjalizacji czasu przeszłego.

Zasygnalizowane powyżej przemiany postaw wobec przeszłości oraz formy i zakres funkcjonowania reliktów przeszłości bądź jej różnych rekonstrukcji uwarunkowane zostały wieloma powiązanymi ze sobą czynnikami kulturowymi, społecznymi, a także ekonomicznymi. Wywarły one przemożny wpływ na stosunek współczesnego człowieka do przeszłości, na kształtowanie wyobrażeń na jej temat, zapatrywania na jej funkcję i znaczenie we współczesnym świecie, jak również formy odnoszenia się do przeszłości, sposoby jej poznawania, doświadczania, prezentowania czy uobecniania przez ludzi. W konsekwencji doprowadziły one nie tylko do przewartościowań w relacjach człowieka z przeszłością, co zaowocowało uformowaniem się specyficznego, ponowoczesnego stosunku do przeszłości, lecz rów- 
nież do zmiany hierarchii celów przez instytucje zajmujące się przeszłością na gruncie naukowym. Miały one także duży wpływ na formę i odbiór współcześnie kreowanych przez archeologię wizerunków przeszłości, a także na funkcjonowanie archeologii jako dyscypliny badającej przeszłość pradziejową i upowszechniającej wiedzę o tejże przeszłości w przestrzeni społecznej, w zakresie m.in. edukowania czy popularyzowania tego tematu.

\section{STRATEGIE UOBECNIANIA PRZESZLOŚCI TWORZONEJ PRZEZ ARCHEOLOGIE}

Strategie uobecniania przeszłości i same formy obecności przeszłości pradziejowej we współczesności, sposoby rekonstruowania, przywoływania czy przedstawiania wiedzy na temat przeszłości społeczeństwu i konsekwentnie metody jej poznawania bądź/i doświadczania przez człowieka ujawniają się obecnie w kilku tendencjach (trendach mobilizacyjnych), a są to: (1) sensacjonizm odkryć archeologicznych; (2) rekonstrukcjonizm; (3) teatralizacja/performatywizm przeszłości oraz (4) festiwalizacja przeszłości.

Pierwsza $\mathrm{z}$ wymienionych tendencji - sensacjonizm - oznacza nastawienie na takie wydarzenia, które mogą przyciągnąć uwagę odbiorców, tym samym zaś zapewnić popularność tymże wydarzeniom. Odnosi się do zaskakujących i niespodziewanych odkryć bądź wydarzeń, które zwracają powszechną uwagę, wywołują żywe zainteresowanie bądź poruszenie i są nagłaśniane w różnych mediach: w prasie, telewizji czy internecie. Poprzez sensacjonizm odkryć archeologicznych należy rozumieć ograniczanie się do tematów atrakcyjnych z punktu widzenia mediów oraz ich odbiorców, skupianie się na awanturniczych i przygodowych aspektach pracy archeologa, szukanie sensacji archeologicznych, odnoszenie się jedynie do sensacyjnego aspektu znalezisk i odkryć archeologicznych, podkreślanie ich wyjątkowości kosztem poważnej oceny naukowej, z jednoczesnym pomijaniem innych, ważnych z punktu widzenia archeologii, odkryć oraz ustaleń (Jarosz 2011, s. 75, 2012; Kokowski 2011, s. 14).

Większość archeologów wskazuje, że tendencję do takiego postrzegania archeologii bądź archeologów należy uznać za szkodliwą, gdyż ma ona niewiele wspólnego z tym, czym w rzeczywistości zajmuje się ta dyscyplina naukowa, przez co zaś wypacza jej prawdziwy wizerunek. Postrzeganie archeologii i jej odkryć przez pryzmat sensacji, pomimo licznych mankamentów, niekoniecznie jednak musi mieć negatywną wymowę, gdyż w pewnym zakresie decyduje to o popularności oraz atrakcyjności archeologii w odbiorze społecznym i we współczesnej kulturze, o swoistej „koniunkturze” na archeologię. Przykładem takich zabiegów mogą być stosunkowo niedawne doniesienia na temat odkrycia „Warmińskich Pompejów” pozostałości pierwszej średniowiecznej lokacji obecnego Barczewa, mianowicie 
reliktów grodziska z XIV w., które zostało zniszczone w wyniku najazdu litewskich wojsk księcia Kiejstusa. Jak zaznacza kierujący badaniami Arkadiusz Koperkiewicz:

To prowokacyjnie wymyślona nazwa; wiadomo, czym Pompeje są dla archeologii. Tu jest podobna sytuacja, że jakieś nagłe zdarzenie udokumentowane historycznie spowodowało, że mamy doskonale zachowaną strukturę jednego z najstarszych miast na tym terenie. To jest miejsce wymarzone dla archeologów, bo można obserwować „w pigułce” zatrzymany czas (cyt. za: http://www.naukawpolsce.pap.pl/aktualnosci/news,401457,ar cheolodzy-odkryli-warminskie-pompeje---grodzisko-z-xiv-wieku.html).

Strategia ta nie jest zatem jedynie wytworem mediów, lecz często jest podtrzymywana i stosowana przez samych archeologów w myśl zasady, że z racji jej silnego oddziaływania i potencjału perswazyjnego umiejętne wykorzystane takiej taktyki może służyć do autopromocji archeologii we współczesnym świecie i kreowania pozytywnego wizerunku archeologów.

Z kolei rekonstrukcjonizm oznacza zabiegi odtwarzania/rekonstruowania elementów dawnej rzeczywistości poprzez jej materialne (rzeczywiste) bądź wirtualne rekonstrukcje, głównie pełnowymiarowe rekonstrukcje budowli lub ich zespołów, często wraz z ich otoczeniem. Dotyczy to także odtwarzania narzędzi, urządzeń czy ogólnie zabytków, których istnienie zostało potwierdzone przez źródła archeologiczne lub historyczne: tworzenie kopii bądź replik określonych zabytków, rekonstrukcje narzędzi, broni, uzbrojenia oraz przedmiotów codziennego użytku w przeszłości. W takim aspekcie odnosi się zarówno do archeologii eksperymentalnej (np. Coles 1977; Petersson, Narmo 2011), jak i odtwórstwa historycznego (np. Radtchenko 2006; Bogacki 2008, 2010) w jego wymiarze przedmiotowym, czyli produkowania mniej lub bardziej zgodnych z oryginalnymi pierwowzorami kopii pewnych zabytków bądź przedmiotów. Najbardziej jednak złożony aspekt rekonstrukcjonizmu to odtwarzanie przeszłości przez pełnowymiarowe materialne rekonstrukcje w formie skansenów, rezerwatów bądź parków archeologicznych, jak również replik pradziejowych grodów czy osad, które tworzone są m.in. w celach naukowych, edukacyjnych, a także turystycznych (Brzeziński 1998, s. 65; Paardekooper 2012; Pawleta 2011a, s. 41-44). Termin rekonstrukcjonizm jest więc bliski pojęciu materializacji w znaczeniu nadawania przeszłości i jej poszczególnym elementom materialnych, realnych kształtów, stawaniu się czymś konkretnym i rzeczywistym, przez co staje się ona zarówno widzialna, jak i namacalna w teraźniejszości. Jak można przeczytać na temat skansenu archeologicznego „Karpacka Troja” w Trzcinicy:

W Parku Archeologicznym została zrekonstruowana wioska ludności kultury Otomani-Füzesabony sprzed 3,5 tys. lat oraz wioska słowiańska i kuźnia z IX-X wieku. Tu znajduje się miejsce na obozy wojów, pokazy walk i dawnego rzemiosła oraz warsztaty łucznicze i archeologiczne. Tu na specjalnie wyznaczonym i zaoranym skrawku ziemi uprawia się rośliny, jakie wysiewali mieszkańcy grodu. Tu odbywa się wiele przedsięwzięć 
z zakresu archeologii doświadczalnej i rekonstrukcyjnej. [...] Tu można wczuć się dobrze w życie codzienne dawnych mieszkańców i prawdziwie dotknąć przeszłości (Gancarski 2012, s. 116).

Zazwyczaj rekonstrukcje oparte są na odkrytych w trakcie wykopalisk pozostałościach archeologicznych bądź źródłach historycznych; często zdarza się jednak, że stanowią one jedynie hipotetyczne rekonstrukcje, które nie mają poświadczenia w dostępnej ewidencji źródłowej, a oparte są jedynie na analogiach. Znaczenie rekonstrukcji zostało dostrzeżone w praktyce konserwacji zabytków, pośrednio zaś w archeologii, i wyrażone w zaleceniach zawartych choćby w Karcie Weneckiej (1964) oraz Karcie Lozańskiej (1990). Wskazywały one, że rekonstrukcje spełniają funkcje badań eksperymentalnych oraz objaśniania, a także podkreślały, że zabytki powinny być odtwarzane z zasadą zachowania autentyczności. Główną zaletą wszelkiego typu rekonstrukcji, zwłaszcza pełnowymiarowych, jest ich ilustracyjność, jako że wizualizują oraz uplastyczniają one wizerunek przeszłości kreowany za pośrednictwem archeologii. Pozwalają osadzić dany przedmiot czy budowlę w pewnym kontekście, objaśniając w ten sposób jego możliwe funkcje, kreując przez to dość perswazyjny efekt wizualny; są więc odpowiednie do tłumaczenia abstrakcyjnych pojęć (Blockey 1998, s. 72). Rekonstrukcje grodów czy osad stanowią ponadto doskonałą scenerię do organizowania np. festynów archeologicznych i wszelkiego typu inscenizacji „ożywiających” przeszłość. Pełnowymiarowe, materialne rekonstrukcje przeszłości organizują więc poznawanie i doświadczanie przeszłości w sposób bardziej skuteczny i perswazyjny aniżeli słowna narracja. Aczkolwiek niektórzy badacze (np. Sommer 1999, s. 167) twierdzą, że poprzez wszelkiego typu rekonstrukcje oferowany jest nam kontakt z czymś sztucznym, nieoryginalnym, z substytutami przeszłości, odbieranymi jednak przez wiele osób tak, jakby były autentycznymi pozostałościami z przeszłości.

Kolejną tendencję określam mianem teatralizacji (performatywizmu) przeszłości. Teatralizację należy rozumieć jako „nadawanie czemuś stylu teatralnego, charakteru widowiska, posługiwanie się konwencją teatralną" (Kwiek 2007, s. 76), gdzie jej podstawowe środki stanowią kostium oraz działania aktorskie. Teatralizacja przeszłości, w znaczeniu występów oraz przedstawień, związana jest z odgrywaniem na żywo w obecności widzów przez odtwórców (aktorów) przebranych w stroje z epoki określonych działań odtwarzających bądź obrazujących pewne aspekty i sceny życia w przeszłości. Substancję tychże działań stanowi przekaz treści narzuconych w postaci konkretnych sekwencji jakiegoś wydarzenia z przeszłości czy nawiązanie do hipotetycznego stanu przeszłej rzeczywistości. Działania w tym zakresie mogą mieć mniej lub bardziej złożoną formę: od prostych demonstracji i pokazów po złożone, zaplanowane, angażujące setki osób oraz wyreżyserowane inscenizacje. Przykładowo: na temat XIV Międzynarodowego Zjazdu Wojowników Słowiańskich, odbywającego się w Grzybowie w 2013 r., czytamy: 
Po raz kolejny grzybowski gród przeniósł nas w czasy wczesnego średniowiecza. Zjazd, czternasty z kolei, był wydarzeniem, na którym pokazaliśmy gościom siłę bojową oddziałów zbrojnych z czasów Mieszka I i Bolesława Chrobrego - załogi grodu w Grzybowie. Jednocześnie zaprezentowaliśmy obóz, oddziały, szyki, umiejętności posługiwania się bronią oraz warsztaty wytwórców militariów. Pokazaliśmy również, jakimi metodami posługiwali się rzemieślnicy przy wyrobie wszelakiego dobra oraz niewiasty przy przygotowywaniu strawy. Kulminacyjnym punktem imprezy była inscenizacja ceremonii pogrzebu poległych w bitwie komesa grodu i drużynnika. Jak zawsze punktem kulminacyjnym była bitwa z udziałem ponad setki wojowników. Przed grodem odbywał się jarmark różności. W Zjeździe wzięło udział 560 uczestników w strojach z okresu wczesnego średniowiecza. W ciągu dwu dni imprezy grodzisko w Grzybowie odwiedziło około 12 tys. turystów, w tym również z odległych terenów Polski, Europy (i nie tylko) (cyt. za: http://www.grodgrzybowo.pl/asp/pl_start.asp?typ=14\&sub=4\&menu=55\&strona=1).

Omawiana tendencja związana jest głównie z odtwórstwem historycznym, inscenizacjami życia w pradziejach, festynami archeologicznymi, w mniejszym stopniu z prezentacjami i pokazami w ramach archeologii eksperymentalnej. Teatralizacji przeszłości nie należy odnosić wyłącznie do wzorca teatru jako pewnego wydarzenia, lecz w szerszym kontekście: do form przekazu określonych treści $\mathrm{w}$ postaci prezentacji, przedstawień oraz inscenizacji, przyjmujących teoretycznie postać teatralnej praktyki. Odtwarzanie, przedstawianie przeszłości to także forma swoistego performansu (stąd performatywność/perfomatywizm), rozumianego jako zorganizowane działanie człowieka przed widownią, odnoszące się do ludzkiego działania oraz wypowiedzi, prowadząca w efekcie do „dramatyzowania przeszłości w ramach jej odgrywania, odczuwania miejsca i przestrzeni oraz działania ciała" (Marciniak 2012, s. 172-173; zob. też Pearson, Shanks 2001, s. xiii-xiv). Performatywizm ma związek z nowymi formami doświadczania przeszłości, emocjonalnym zaangażowaniem oraz przeobrażeniem widza w aktywnego uczestnika wydarzeń (Ziębińska-Witek 2011, s. 76). W tejże tendencji silnie zauważalna jest interaktywność, częste rezygnowanie z podziału na scenę i kulisy przedstawień, a także na aktywnego nadawcę i pasywnego odbiorcę na rzecz dynamicznego procesu interpretującego przeszłość w formie przedstawienia.

Ostatnia z wymienionych tendencji, festiwalizacja przeszłości, określa organizowanie różnorodnych, zazwyczaj widowiskowych imprez, odnoszących się do przeszłości, o różnym zasięgu, tematyce i charakterze, adresowanych do szerokiego kręgu odbiorców w różnym wieku, odbywających się cyklicznie lub jednorazowo, głównie w postaci różnego rodzaju festynów, festiwali bądź pikników archeologicznych czy imprez plenerowych o tematyce archeologiczno-historycznej, a także inscenizacji odtwórstwa historycznego. Przykładowo: na temat cyklicznego festiwalu Słowian i Wikingów na Wolinie, którego 20. edycja odbyła się w 2014 r., można przeczytać: 
Podczas trzech dni trwania festiwalu Wikingowie, Słowianie, Bałtowie, Madziarzy, Rusini oraz potomkowie innych ludów rozbijają w Wolinie repliki dawnych namiotów, drzewnymi metodami przygotowują strawę, lepią garnki, tkają materiał na ubrania, kują żelazo, ze srebra i brązu odlewają kopie wczesnośredniowiecznej biżuterii, szyją buty, a z drucianych kółek splatają kolczugi. W tym samym czasie po Dziwnie żeglują repliki wikińskich i słowiańskich okrętów z dziobami zwieńczonymi smoczymi łbami. Największą atrakcją są jednak bitwy, podczas których ścierają się z sobą setki wojowników (cyt. za: http://www.jomsborg-vineta.com/festiwal.html).

Festiwalizacja przeszłości, którą synonimicznie można również określić jako festiwalowość, jest pochodną fenomenu festiwalizacji współczesnej kultury, łączącej się z tendencją do jej karnawalizacji (zob. Grad, Mamzer 2004). Posiada ona silny związek z popularyzowaniem wiedzy na temat odległej przeszłości w społeczeństwie oraz współczesnymi sposobami edukowania na jej temat, podejmowanymi m.in. przez placówki muzealne, instytucje naukowe, amatorskie stowarzyszenia czy grupy odtwórstwa historycznego (bądź też wspólnymi siłami). Zakłada się, iż festyny, podczas których w interaktywny sposób prezentowane są aspekty życia człowieka w przeszłości, przy jednoczesnej atrakcyjności form przekazu, stanowią skuteczny sposób na skoncentrowanie publicznej uwagi na przeszłość pradziejową oraz badającą ją archeologię (np. Abłamowicz 2010, s. 21-24; Brzostowicz 2009, s. 296; Bursche, Chowaniec 2009; Chowaniec 2010, s. 208-217). Festiwalizacja przeszłości odnosi się do intensyfikacji pewnych zjawisk odtwarzających życie w przeszłości, zróżnicowanych pod kątem zarówno skali, jak i poziomu profesjonalizmu, stanowiących jeden z podstawowych sposobów kontaktu współczesnego człowieka z pradziejami. Wpływa ona w znaczący sposób na kształtowanie stanu wiedzy na ich temat, jak również stanowi ekspresję działań odtwarzających dawne dzieje w postaci masowo dostępnej.

Proponuję ujmować wydzielone tendencje jako strategie, a jednocześnie jako terminy służące nazwaniu, uporządkowaniu, interpretacji i opisowi określonych działań związanych z uobecnianiem archeologicznie kreowanej przeszłości. Trudno je przy tym wyraźnie od siebie oddzielać, gdyż zazwyczaj na wielu płaszczyznach wzajemnie się ze sobą przeplatają i uzupełniają, np. w trakcie festynu archeologicznego. Twierdzę, że tendencje te, będące pochodną szerszych procesów społeczno-kulturowych, stanowią wyraz poszukiwania nowych sposobów mówienia o przeszłości, jej prezentowania, popularyzowania oraz edukowania w tym zakresie, opartych na atrakcyjności, masowym dostępie oraz uczestnictwie. Ponadto są one wyrazem nowych form kontaktu współczesnego człowieka z odległą przeszłością, bazujących głównie na jej doświadczaniu. Stanowią pewien skonwencjonalizowany sposób społecznej regulacji stosunku do przeszłości, jednocześnie zaś świadectwo pojawienia się pewnych zjawisk w kulturze historycznej współczesnego społeczeństwa polskiego oraz kształtowanie się odmiennego - w porównaniu z poprzednią epoką - stosunku człowieka do przeszłości. Chciałbym w tym miejscu wyraźnie 
podkreślić, że w przypadku zasygnalizowanych tendencji o byciu novum nie decyduje fakt, iż we wszystkich aspektach stanowią one dotychczas nieznane elementy, treści czy jakość, gdyż - jak choćby w odniesieniu do rekonstrukcji archeologicznych - odnoszą się do zjawisk istniejących od dawna. Chodzi raczej o ich intensywność i kontekst współczesnego świata, w którym zachodzą, co składa się na specyfikę ich wymowy oraz znaczenia.

\section{CHARAKTERYSTYCZNE ELEMENTY STOSUNKU WSPÓLCZESNEGO CZLOWIEKA DO PRZESZŁOŚCI}

W zdefiniowanych powyżej tendencjach przejawia się kilka charakterystycznych elementów współczesnego stosunku człowieka do przeszłości, w tym przeszłości pradziejowej, będącej przedmiotem badań, interpretacji i rekonstrukcji archeologów. Jednym z nich jest postępująca demokratyzacja podejść do przeszłości, którą należy rozumieć jako stopniowe różnicowanie się interpretacji przeszłości, funkcjonujących w przestrzeni społecznej, otwarcie się akademii na różnorodność wizji pradziejów oraz możliwość wykorzystywania jej w różnych celach - w związku z tym niejednokrotnie dochodzi do współistnienia różnych, często niewspółmiernych względem siebie wersji przeszłości (zob. Nora 2010). Archeologia, w tym archeologia polska, uświadomiła sobie, iż nie może być dłużej praktykowana i rozumiana tylko i wyłącznie z czysto naukowego punktu widzenia, ponieważ w konsekwencji licznych przemian zachodzących w ciągu ostatnich dekad w wielu kontekstach wchodzi ona we wzajemne interakcje ze społeczeństwem. O ile refleksja nad relacją między badaniami oraz odkryciami archeologicznymi a zainteresowaniami społecznymi jest kwestią niezmiernie interesującą, o tyle wymaga ona osobnych studiów - i z powodu braku miejsca nie zostanie podjęta w niniejszym artykule.

Przejawy demokratyzacji stosunku do przeszłości są widoczne w stopniowej utracie przez akademię (archeologię) monopolu na interpretowanie przeszłości i tworzenie jej prawomocnych czy powszechnie obowiązujących wizerunków. Demokratyzacja podejść do przeszłości polega więc na stopniowym wyłanianiu się i dopuszczaniu do głosu alternatywnych wobec akademickich interpretacji przeszłości, tworzonych np. w ramach społeczności plemiennych (Hodder 1995, s. 200-202; Johnson 2013, s. 218-224). Przejawia się ponadto w różnych zapatrywaniach na współczesne znaczenie oraz wykorzystywanie stanowisk archeologicznych, także w Polsce. Przykładem tego są m.in. stanowiska z kręgami kamiennymi z okresu wpływów rzymskich na Pomorzu (Siemiński 2004; Walenta 2006; Skitek 2012) czy góra Ślęża i jej okolice (Matela 2006; Beźnic, 2011; Pawleta 2011c). Kolejną ilustracją demokratyzacji stosunku do przeszłości są także interpretacje przeszłości alternatywne wobec archeologicznych - nie zawsze akceptowane przez zawodowe 
środowisko archeologiczne, czego najbardziej dobitnym exemplum jest nurt tzw. pseudoarcheologii (Feder 2002; Fagan 2006). Ponadto należy do nich zaliczyć indywidualizację perspektywy oglądu przeszłości i zainteresowanie tzw. małą historią, w wymiarze nie tyle narodowym, ile przede wszystkim lokalnym, regionalnym (,prywatyzacja” przeszłości). Innym aspektem tego procesu jest także to, że akademickie (profesjonalne) narracje na temat przeszłości przestają stanowić jedyne źródło kulturowych obrazów i wyobrażeń o pradziejach - w kreowaniu i upowszechnianiu wiedzy o przeszłości zwiększa się rola amatorów, ludzi, którym obcy jest naukowy warsztat metodologiczny czy teoretyczny, np. grup rekonstrukcji historycznych, twórców alternatywnych portali historycznych, producentów gier komputerowych itd. (Woźniak 2010, s. 77-80). Coraz częściej na temat dziedzictwa archeologicznego i form jego przedstawiania zaczynają się wypowiadać nieprofesjonaliści. Stanowi to duże wyzwanie dla archeologii, wobec którego dziedzina ta musi się ustosunkować, gdyż $\mathrm{w}$ rezultacie proces ten prowadzi do stopniowego zacierania się różnic pomiędzy nauką a innymi formami tworzenia wiedzy o przeszłości i do podważania roli profesjonalnej archeologii w tworzeniu prawomocnych narracji na temat przeszłości. Wreszcie demokratyzacja stosunku do przeszłości skutkuje umasowieniem dostępu do niej, raptowną intensyfikacją użytków czynionych z przeszłości i jej dziedzictwa, m.in. politycznych, turystycznych czy handlowych (Nora 2010, s. 141), co powoduje nie tylko rozprzestrzenianie się różnych wersji przeszłości, ale często także ich nieuniknioną komercjalizację.

Drugim, charakterystycznym elementem współczesnego stosunku do przeszłości jest potrzeba i poszukiwanie bezpośredniego kontaktu z nią bądź jej rekonstrukcja$\mathrm{mi}$ / inscenizacjami oraz zmysłowe formy doświadczania przeszłości. Liczni autorzy wskazują, że współcześnie doszło do wykształcenia się takiego stosunku do czasów minionych, gdzie zmysłowość bierze górę nad intelektualnymi formami kontaktu z przeszłością. W kulturze historycznej człowieka obecnej epoki wizualnej, jak zauważa Andrzej Szpociński (Szpociński 2010, s. 16, 26), dominują głównie przekazy pozawerbalne, obrazy, happeningi, performanse; to nie przeżycia intelektualne, lecz głównie zmysły odgrywają główną rolę w doświadczaniu przeszłości i jej poznawaniu, dostarczając odbiorcy określonych doznań estetycznych, umożliwiając też uczestnictwo we wspólnocie danego widowiska. Jednym z przejawów tendencji do bezpośredniego, prywatnego i autentycznego kontaktu z przeszłością jest proponowany, zamiast biernego przyglądania się rekonstrukcjom historycznym, bardziej interaktywny model uczestnictwa w nich, angażujący widzów. Innym przykładem jest wcielanie się w role osób z przeszłości, co umożliwia m.in. udział w ruchu rekonstrukcyjnym, inscenizacje odtwórstwa historycznego, zjawisko tzw. podróży w czasie (zob. Holtorf 2009), w określonym zakresie także wizyty w skansenach archeologicznych, których zwiedzanie jest planowane w taki sposób, by oddziaływało jednocześnie na jak największą ilość zmysłów. Na temat rekonstrukcji średniowiecznej warowni „Sławogród” niedaleko Czaplinka czytamy: 
Sławogród nie jest zwykłym skansenem. Cała osada tętni życiem. Niedaleko palisady znajduje się zagroda ze zwierzętami, przy chacie rosną zioła, z których gospodyni robi wywary i leki. Grodziska pilnują dzielni wojowie, którzy odpierają ataki barbarzyńskich sąsiadów i obcych plemion. Na krośnie niewiasty tkają piękne materiały, a z kuźni sypią się bogato iskry, które wznieca kowal! Możesz tu odwiedzić najstarszego i najmądrzejszego męża, który opowie ci o dawnych bogach i odsłoni przyszłość używając magicznych run. Stragany uginają się pod ciężarem bogatej oferty kupców, którzy zwożą towary ze wszystkich stron świata (cyt. za: http://www.slawogrod.eu/cms/).

Istotne w przypadku wzmiankowanej postawy jest przekonanie o możliwości osobistego i bezpośredniego wglądu w przeszłość i doświadczania jej za pomocą zmysłów oraz partycypacji w wydarzeniach odtwarzających przeszłość. Dzięki temu „praktyki uobecniania przeszłości nabierają szczególnych form: chodzi o to, by poczuć, dotknąć, doświadczyć" (Tarkowska 2012, s. 30). Główną kategorią takiego kontaktu z przeszłością jest jej przeżywanie, zanurzenie się w miniony świat i doświadczanie go w sposób zmysłowy, obejmujący „możliwość dotykania, wąchania i smakowania owych światów w przedmiotach, które je tworzyły" (Gumbrecht 2002, s. 197-198). W takim kontekście można mówić o swoistej „sensualizacji” przeszłości.

Z zagadnieniem zmysłowego doświadczania przeszłości bezpośrednio połączony jest kolejny element, składający się na formułę współczesnego podejścia do przeszłości, mianowicie: kwestia autentyczności przeszłości i jej reliktów oraz bezpośredniego kontaktu z przeszłością. Autentyczność w wąskim rozumieniu odnosi się jedynie do oryginalności (głównie do materii), oznaczając prawdziwość, np. muru czy malowidła pradziejowego. Decyduje o niej przede wszystkim prawdziwość substancji zabytkowej, przy czym za wartościowy uznaje się nie tyle obiekt zabytkowy przywrócony do stanu pierwotnego, ile zabytek, który zawiera nakładające się na siebie ślady działalności człowieka w różnych okresach, tzw. historyczny palimpsest (Jones 2009, s. 134; Kobyliński 2001, s. 82). Pojęcie autentyczności stanowi jedno z podstawowych pojęć w dziedzinie konserwacji oraz ochrony zabytków, budząc jednocześnie liczne dyskusje i wątpliwości. Jest ono miarą wartości zabytkowych dziedzictwa (archeologicznego), przesądza o konieczności ochrony i zachowania danego obiektu bądź miejsca dla potomnych. W takim wymiarze stanowi ono źródło wartości zabytkowych dziedzictwa archeologicznego, które sprawiają, iż obiekt czy przedmiot jest prawdziwym, wiarygodnym przekazem z przeszłości. Autentyczność zabytku z kolei warunkuje inne wartości zabytkowe dziedzictwa, jak np. jego wartość źródłową czy emocjonalną, wynikającą z możliwości kontaktu człowieka z rzeczywistym przedmiotem z przeszłości (Kobyliński 2001, s. 81), dlatego tak ważne jest jej zachowanie, w tym autentycznej tkanki i materialnej integralności zabytków. W szerszym natomiast rozumieniu odchodzi się od tej uniwersalności łączonej z oryginalnością oraz dopuszcza, że ten sam przedmiot może oznaczać coś innego dla różnych ludzi oraz że autentyczność może oznaczać co innego w różnych kon- 
tekstach kulturowych (Marciniak 2013, s. 44). Dokument z Nara o autentyczności (1994) stwierdza, że nie jest możliwe opieranie jej oceny na stałych kryteriach, lecz musi to być oceniane w kontekście kultury, do której należy i w oparciu o kryteria właściwe kulturze, do której przynależy to dziedzictwo.

Jest rzeczą oczywistą, iż we wszelkich rekonstrukcjach archeologicznych czy inscenizacjach przeszłości nie jest możliwy kontakt $\mathrm{z}$ autentycznymi reliktami z przeszłości - z tej prostej przyczyny, iż stanowią one jedynie ich kopie, naśladownictwa, są one pozbawione swoistej aury i autentyczności towarzyszącej oryginalnym zabytkom, wynikającej „z więzi oryginału z miejscem i czasem istnienia” (Benjamin 1996, s. 205). Jednakże tego rodzaju stosunek do dziedzictwa kulturowego nie musi być pozbawiony znamion autentyczności, gdyż może przyjmować formę tzw. autentyczności gorącej, a więc prawdziwego przeżycia, którego zwiedzający doświadcza w kontakcie z przeszłością lub jej rekonstrukcjami (Selwyn 1996, s. 7-8; cyt. w: Wieczorkiewicz 2008, s. 41-42). Definiuje ona tym samym autentyczność kontaktu z przeszłością za pośrednictwem jej kopii, replik czy inscenizacji odtwarzających minione dzieje. Wydaje się bowiem, że dla wielu turystów autentyczność odtworzonych rzeczywistych miejsc z przeszłości nie ma znaczenia, ale istotna jest sama ich wartość, pewna sceneria, wywołująca poczucie „dawności”, w której cieszą się odbieraniem zmysłowych bodźców oraz doświadczaniem tych miejsc, czyli wystarcza im samo wrażenie autentyczności. Jak zauważają bowiem niektórzy autorzy (np. Baudrillard 2005; Ritzer 2004), operowanie w świecie symulakrów i doświadczanie sztucznej rzeczywistości dla wielu osób może być tak samo, a często o wiele bardziej prawdziwe, urzekające bądź inspirujące niż obcowanie ze światem ,realnym”.

Innym, diagnostycznym elementem współczesnego stosunku do przeszłości jest zjawisko estetyzacji przeszłości. W potocznym rozumieniu estetyzację można ujmować jako zabieg bądź czynność sprawiającą, że coś staje się ładne lub gustowne (Gołyszny 2011, s. 219), bądź jako czynienie czegoś estetycznym, co samo w sobie estetyczne nie jest (Mamzer 2008, s. 67). W takim aspekcie kryterium estetyczne zakłada, że aby coś mogło przyciągnąć uwagę ludzi, musi być estetyczne, ładne oraz atrakcyjne. Zjawisko estetyzacji przeszłości paradoksalnie jest możliwe dzięki temu, że przeszłość minęła, my zaś, znając jej zakończenie czy, odwołując się do Davida Lowenthala (Lowenthal 1985, s. 234), „wynik przeszłości”, używamy tej wiedzy do kształtowania współczesnych wizerunków przeszłości; kierując się wyobraźnią, możemy dowolnie konstruować jej obraz tak, by był kompletny, żywy, przekonujący bądź estetyczny. Estetyczne kreacje przeszłości niejednokrotnie idą w parze z oczekiwaniami odbiorców, odpowiadając pewnym obowiązującym zasadom prezentacji obiektów, rzeczy bądź ludzi z przeszłości. Mam na myśli tzw. estetykę powierzchni, która jest zgodna ze sposobem przejrzystego, niezakłóconego prezentowania obiektów pozbawionych wielu towarzyszącym im w rzeczywistości elementów (Gwóźdź 2004, s. 89). Widoczne jest to np. w inscenizacjach historycznych: 
[...] pokazy rekonstrukcyjne udostępniają nam historię zdekontekstualizowaną, ukazując wyłącznie wycinek historii (z reguły o militarnym charakterze), który może zostać odtworzony w dowolnej przestrzeni. Usunięcie oznak cierpienia (krew, strzępki ciał, płacz, prawdziwa przemoc) i nadanie obserwującym roli raczej widzów niż świadków, pozostawienie ich za bezpiecznymi barierkami oddzielającymi historię od teraźniejszości tworzy z tego typu pokazu atrakcyjny produkt, który może zostać skonsumowany równie dobrze przez uczestników obchodów rocznicowych, jak i przez klientów supermarketów (cyt. za: http://historiaimedia.org/2011/08/16/rekonstrukcje-historyczne-i-estetyzacjaprzeszlosci/).

Estetyzację przeszłości w archeologii można obserwować m.in. na wystawach muzealnych, na których widoczne jest wyjątkowe traktowanie przedmiotów (zabytków) o charakterze utylitarnym, pozbawionych wartości estetycznych, a eksponowanie ich w sposób nieomal dekoracyjny - jedynie dlatego, że stanowią pozostałości minionych kultur (Mamzer 2008, s. 65). Estetyzacja przeszłości widoczna jest również we wszelkich próbach jej ożywiania poprzez transformację fragmentarycznej wiedzy na jej temat w formę całościowych, teatralnych przedstawień minionego życia. Wpisana jest ona także w podejmowane zabiegi odtwarzania przeszłości tworzenie kompletnych i pełnowymiarowych rekonstrukcji na podstawie dostępnych źródeł, w celową historyzację elementów rzeczywistości lub nadawanie im ,patyny dawności”, a także kreacji ex nihilo - np. parków archeologicznych, które w prezentowanej formie nigdy w minionej rzeczywistości nie istniały, co przydaje im znamion Baudrillardowskich symulakrów (Baudrillard 2005). Estetyzacja przeszłości jest szczególnie widoczna w wirtualnych rekonstrukcjach archeologicznych, gdzie tworzone i prezentowane są wizerunki oraz obrazy przeszłości w sposób dalece zaaranżowany, kompletny, estetycznie modelowany. O estetyzacji przeszłości świadczy zatem zarówno sam sposób informowania o niej w sposób atrakcyjny dla odbiorców, za pośrednictwem rekonstrukcji, wystaw muzealnych, spektakli odtwórstwa historycznego czy festynów archeologicznych, jak i odnosi się ona do opartego na przeżyciu archeologicznego doświadczania przeszłości i jej odkrywania, któremu towarzyszy niezwykła aura oraz związane z tym emocje (Shanks 1992, s. 138-141; Pawleta 2011b, s. 36-38).

Następna kwestia odnosi się do zjawiska utowarowienia oraz komercjalizacji przeszłości (szerzej na ten temat zob. Pawleta 2011a). Utowarowienie to konwersja dóbr kulturowych w zasoby, przekształcanie wartości użytkowej w wartość wymienną, wskutek czego produkty kulturowe zamieniane są w towar oceniany na podstawie potencjalnego zysku, jaki przynosi. Zabiegi utowarowienia/komercjalizacji przeszłości konsekwentnie należy rozumieć jako eksploatowanie, eksponowanie, sprzedawanie i konsumowanie przeszłości (historii) i jej materialnego dziedzictwa jako produktów o wartości rynkowej oraz podejmowanie wysiłków zmierzających do uczynienia $\mathrm{z}$ nich rozpoznawalnego produktu marketingowego (Rowan, Baram 2004). Przedmiot komercjalizacji stanowi przeszłość zarówno 
w postaci materialnych reliktów (zabytków) bądź ich kopii, jak i wszelkich narracji na temat przeszłości, tworzonych na podstawie tych reliktów, m.in. filmy, książki, rekonstrukcje archeologiczne, inscenizacje historyczne czy festyny archeologiczne (szerzej na ten temat - zob. Pawleta 2010). W efekcie komercjalizacji przeszłość bywa traktowana jako surowiec dla współczesnych zainteresowań i wykorzystania, dziedzictwo zaś jako celowo stworzony wytwór służący zaspokajaniu potrzeb konsumpcyjnych. Na przykład w dość sarkastycznym tonie na temat biskupińskich festynów pisze Michał Foerster:

Na zwłokach powstała rekonstrukcja bazująca na kulturze popularnej. Biskupin jako hipermarket, gdzie popielnicę twarzową kultury pomorskiej można kupić za trzydzieści złotych, a kultowy kubek do trzymania ołówków za trzynaście, radzi sobie świetnie. Świadczą o tym tłumy turystów dosłownie oblegające gród; oto współcześni Germanie, którzy ostatecznie zdobyli i zawładnęli prahistorią (cyt. za: http://esensja.stopklatka.pl /magazyn/2008/06/iso/12_12.html).

Dowolne sposoby przywoływania, reprodukowania, ożywiania przeszłości w kontekście kultury konsumpcyjnej powodują z kolei, że przeszłość sama w sobie staje się coraz bardziej zbyteczna, co prowadzi do swoistej atrofii jej znaczenia:

[...] wyszukane i inspirujące nazwy (W cieniu piramid, Wczasy piastowskie), będące legitymizacją ambitnego programu, zatracają swoje pierwotne znaczenia i stają się kolejnymi hasłami reklamowymi. Przeszłość sama w sobie nie jest potrzebna, tym bardziej jej znaczenie (Jasiewicz, Olędzki 2005, s. 203).

Wreszcie przeszłość, formy odnoszenia się do niej, jej przedstawiania oraz doświadczania obecnie w coraz większym stopniu stają się źródłem zachowań ludycznych; uobecnianie przeszłości można więc postrzegać jako zjawisko ludyczne (szerzej na ten temat zob. Pawleta 2011b). Dotyczy to również archeologicznie kreowanej przeszłości, która może stać się inspiracją do poszukiwania przyjemności, będąc obecnie jednym z bardziej popularnych sposobów poznawania, odczuwania oraz rozumienia tejże przeszłości, głównie za pośrednictwem szeroko pojmowanej zabawy. Rekonstrukcje archeologiczne czy inscenizacje odtwarzające pewne aspekty życia człowieka $\mathrm{w}$ przeszłości stanowią często źródło lub inspirację do zabaw i wynikających $z$ uczestniczenia $w$ nich przyjemności, zarówno w procesie ,uludyczniania archeologii”, a więc wykorzystania wiedzy archeologicznej do celów ludycznych, jak i zabaw oraz rozrywek, których kanwą jest przeszłość pradziejowa. $\mathrm{W}$ ich zakresie mieszczą się m.in. pokazy walk wojów, koncerty muzyki dawnej, pokazy pradziejowego rzemiosła, zabawy plebejskie, gry i konkursy itd. Przykładowo: na temat drugiej edycji plenerowej imprezy pod hasłem „Kalisz Piastowski” w Kaliszu-Zawodziu czytamy:

To będzie niedziela pełna wrażeń. Wczesnośredniowieczne grodzisko na Zawodziu zamieni się w zagrodę Piasta Kołodzieja - takie jest bowiem hasło przewodnie tegorocznej 
edycji imprezy. Mieszkańcy Kalisza, regionu oraz turyści będą mogli przenieść się w zamierzchłe, średniowieczne czasy, korzystając z licznych atrakcji przygotowanych przez organizatorów.[...] Pojawi się Wioska Kuglarzy, w której „zamieszkają” szczudlarze, połykacze ognia i żonglerzy, będzie można zagrać tam w kości oraz przeciągnąć linę. Stoisko Rybaka, poza prezentacją sprzętu do połowu, umożliwi sprawdzenie swoich wędkarskich umiejętności, a nawet uwędzenie „zdobyczy”. [...] Organizatorzy nie zapomnieli też o najmłodszych. To właśnie z myślą o nich przygotowali akcję „Mały Archeolog”, czyli zabawę w poszukiwanie ukrytych skarbów (http://www.faktykaliskie.pl/ w-zagrodzie-piasta-kolodzieja-festyn-na-zawodzi; zachowana oryginalna pisownia).

Istotne jest, iż w ,zabawach przeszłością” widz nie musi spełniać żadnych warunków wstępnych, nie musi znać historii (przeszłości), by w nich uczestniczyć; ich istotę stanowi bowiem nie tyle wiarygodność historyczna, unikanie anachronizmów bądź fantazjowania, ile głównie spektakularność (Dominiak 2004, s. 84; Kantor 2010, s. 142).

Jednym z istotnych elementów zabawy w przeszłość jest nauka poprzez zabawę, innymi słowy tendencja do ,wykorzystywania mniej dydaktycznych form edukacji, w których afektywne, zmysłowe i zdominowane przez media inscenizacje łączą się z edukacją i tworzą syntetyczną formę zwaną edutainment, edukacją poprzez rozrywkę" (Edensor 2004, s. 115). W zakres tego pojęcia wchodzą wszelkie działania stanowiące formę edukacji nieformalnej, których celem jest połączenie nauki z rozrywką w myśl naczelnej zasady: aby „uczyć bawiąc”. Tendencja ta jest silnie eksponowana w przypadku festynów archeologicznych, których jedną z naczelnych zasad jest, by „uczyć bawiąc” oraz „,bawiąc uczyć” (Brzostowicz 2009, s. 296; Bursche, Chowaniec 2009, s. 74). Mają one za zadanie przekazywanie określonych treści edukacyjnych na temat pradziejów pewnej grupie odbiorców, rozrywka zaś stanowi interesującą, wciągającą oraz atrakcyjną dla odbiorców formę przekazu, dzięki której dużo łatwiej przyswajają sobie wiedzę. Uczestnicy festynów czy inscenizacji wydarzeń z przeszłości mogą więc nie tylko poczuć atmosferę dawnych czasów, ale przede wszystkim, w bardzo oryginalny sposób, bo poprzez zabawę, przyswoić sobie wiedzę o odtwarzanych okresach pradziejów i średniowiecza.

\section{PODSUMOWANIE}

Reasumując, należy stwierdzić, że opisane w artykule sposoby uobecniania przeszłości, podejmowane zarówno z inicjatywy profesjonalnych archeologów, jak i przez amatorów, mają i pozytywne, i negatywne aspekty. Do ich pozytywnych stron zaliczyć można m.in. to, iż oferują one współczesnemu człowiekowi angażujący, interaktywny i zmysłowy kontakt z przeszłością, stanowią doskonały sposób na dotarcie z rzetelnym i atrakcyjnym przekazem do masowego odbiorcy, dobrze realizują ideę popularyzacji wiedzy o przeszłości i archeologii w społeczeństwie, eduku- 
ją na temat przeszłości $\mathrm{w}$ formie zgodnej $\mathrm{z}$ wymaganiami współczesności czy wreszcie: zwiększają społeczną świadomość potrzeby ochrony dziedzictwa archeologicznego. Z kolei wśród negatywnych aspektów należy wskazać np. ich nadmierną komercjalizację, niejednokrotnie niezgodność przedstawień z historycznymi realiami czy aktualnym stanem wiedzy naukowej o danym zagadnieniu, uproszczenia i nierzetelne przedstawienia, brak profesjonalizmu ze strony przedstawiających oraz nikły nadzór naukowy nad przekazywanymi treściami. Ponadto towarzyszy im często utrata funkcji edukacyjnej na rzecz aspektów rozrywkowych, wykorzystywanie przeszłości czy zabytków jedynie w charakterze „fabularnego sztafażu” (Golka 2009, s. 66) dla przedstawień i inscenizacji, przy nastawieniu na ich atrakcyjność, spektakularność oraz widowiskowość, „disneylandyzację” przeszłości, stanowiącą nieunikniony efekt przywracania dziedzictwa archeologicznego w czysto komercyjnym kontekście.

Nie podejmując próby jednoznacznej oceny opisywanych w artykule inicjatyw i zjawisk, gdyż wymaga ona szczegółowej analizy konkretnych przypadków, pragnę wreszcie podkreślić, że chociaż konceptualizacja obecności i funkcjonowania wytworów wiedzy archeologicznej na płaszczyźnie społecznej stanowi dość rzadko eksplorowany na gruncie polskiej archeologii obszar, uważam, iż posiada ona znaczny i rozwojowy potencjał dla tejże dziedziny. Istotne jest jednak wzięcie pod uwagę szerszego kontekstu kulturowego, w którym praktykowana jest archeologia jako dyscyplina naukowa i w którym kreowane są określone wizerunki przeszłości. Sądzę, że aspekty odnoszące się do funkcjonowania wytworów wiedzy archeologicznej w przestrzeni społecznej stanowią realnie inspirujące wyzwanie dla teorii oraz, co istotne, dla współczesnej praktyki archeologicznej, zarówno w kontekście polskim, jak i szerszym, światowym, dostarczając nowych możliwości spojrzenia na przedmiot badań archeologii i kreowanych za jej pośrednictwem wizerunków przeszłości.

$$
* * *
$$

\section{Podziękowania}

Napisanie niniejszego artykułu było możliwe dzięki uczestnictwu w projekcie „NEARCH. New Ways of Community-Involved Archaeology” realizowanym w Instytucie Prahistorii UAM w Poznaniu (2013-2018) ze środków Komisji Europejskiej. Odzwierciedla on wyłącznie stanowisko jego autora, Komisja Europejska zaś nie ponosi odpowiedzialności za jakiekolwiek wykorzystanie zawartych w nim informacji. [Although the article resulted from the project supported by the European Communion, it reflects the views of its author, exclusively, and the Commission should not be held responsible for any use which may be made of information and opinion presented herein]. 


\section{BIBLIOGRAFIA}

Abłamowicz D.

2010 Kilka uwag o kondycji muzeów w Polsce. W: J. Wrzesiński, A.M. Wyrwa (red.), Przeszłość dla przyszłości. Problemy edukacji muzealnej. Materiały Konferencji z okazji Jubileuszu 40-lecia Muzeum Pierwszych Piastów na Lednicy, Lednica 11-13 września 2009 r. (s. 15-31). Lednica: Muzeum Pierwszych Piastów na Lednicy.

Baudrillard J.

2005 Symulakry i symulacja. Warszawa: Wydawnictwo Sic!

Benjamin W.

1996 Dzieło sztuki w dobie reprodukcji technicznej. W: W. Benjamin, Aniot historii (s. 201-239). Poznań: Wydawnictwo Poznańskie.

Beźnic S.

2011 Skarby Ślęży w katastroficznym scenariuszu końca świata w 2012 roku. W: W. Kunicki, J. Smereka (red.), Ślężańskie światy (s. 169-190). Wrocław: Oficyna wydawnicza ATUT.

Blockey M.

1998 Społeczny kontekst rekonstrukcji archeologicznych. W: Z. Kobyliński (red.), Ochrona dziedzictwa archeologicznego w Europie (s. 72-91). Warszawa: SNAP.

Bogacki M.

2008 Wybrane problemy odtwórstwa wczesnośredniowiecznego w Polsce. W: M. Bogacki, M. Franz, Z. Pilarczyk (red.), Kultura ludów Morza Battyckiego, t. II: Nowożytność i wspótczesność (s. 219-269). Toruń: Wydawnictwo Adam Marszałek.

Bogacki M.

2010 „Wżywanie” się w przeszłość - odtwórstwo historyczne a nauka. W: K. Obremski, J. Wenta (red.), Recepcja kultury średniowiecznej w humanistyce (s. 153-196). Toruń: Wydawnictwo Naukowe UMK.

Brzeziński W.

1998 Przeszłość i przyszłość rekonstrukcji stanowisk archeologicznych. W: Z. Kobyliński (red.), Ochrona dziedzictwa archeologicznego w Europie (s. 64-71). Warszawa: SNAP.

Brzostowicz M.

2009 Imprezy historyczne - edukacja czy rozrywka? Kilka refleksji z doświadczeń Festiwali Kultury Słowiańskiej i Cysterskiej w Lądzie nad Wartą. Fontes Archaeologici Posnanienses, 45, s. 293-300.

Bursche A., Chowaniec R.

2009 Festyn archeologiczny w Biskupinie: komercyjny odpust czy promocja dziedzictwa archeologicznego. W: B. Kaim (red.), Blisko i daleko. Księga Jubileuszowa Instytutu

Chowaniec R. Archeologii Uniwersytetu Warszawskiego (s. 69-77). Warszawa: Instytut Archeologii UW.

2010 Dziedzictwo archeologiczne w Polsce. Formy edukacji i popularyzacji. Warszawa: Instytut Archeologii UW.

Chowaniec R., Więckowski W. (red.)

2012 Archaeological heritage: methods of education and popularization (BAR International Series 2443). Oxford: Archaeopress.

Coles J.

1977 Archeologia doświadczalna. Warszawa: PWN.

Deskur K.

2009 Idea public archaeology - edukacja archeologiczna i popularyzacja archeologii. Fontes Archaeologici Posnanienses, 45, s. 283-292. 
Dominiak Ł.

2004 Zabawa w przeszłość. Festyn archeologiczny jako forma karnawału. W: J. Grad, H. Mamzer (red.), Karnawalizacja. Tendencje ludyczne w kulturze współczesnej (s. 81-86). Poznań: Wydawnictwo Naukowe UAM.

Edensor T.

2004 Tożsamość narodowa, kultura popularna i życie codzienne. Kraków: Wydawnictwo Uniwersytetu Jagiellońskiego.

Fagan B. (red.)

2006 Archaeological fantasies: how pseudoarchaeology misrepresents the past and misleads the public. London-New York: Routledge.

Feder K.L.

2002 Frauds, myths and mysteries: science and pseudoscience in archaeology. Mountain View-London-Toronto: Mayfield.

Gancarski J.

2012 Skansen archeologiczny Karpacka Troja w Trzcinicy. Przewodnik. Krosno: Muzeum Podkarpackie w Krośnie.

Golka M.

2009 Pamięć spoleczna i jej implanty. Warszawa: Wydawnictwo Naukowe Scholar.

Gołyszny M.

2011 Estetyzacja przeszłości - wpływ historiografii na postrzeganie współczesnej sztuki.

W: W. Wrzosek (red.), Oblicza przeszłości (s. 219-230). Bydgoszcz: Epigram.

Grad J., Mamzer H. (red.)

2004 Karnawalizacja. Tendencje ludyczne w kulturze wspótczesnej. Poznań: Wydawnictwo Naukowe UAM.

Gwóźdź A.

2004 Technologie widzenia, czyli media $w$ poszukiwaniu autora: Wim Wenders. Kraków: Universitas.

Gumbrecht H.U.

2002 Gdy przestaliśmy uczyć się od historii. W: E. Domańska (red.), Pamięć, etyka, historia. Angloamerykańska teoria historiografii lat dziewięćdziesiątych (s. 187-206). Poznań: Wydawnictwo Poznańskie.

Hodder I.

1995 Czytanie przeszłości. Współczesne podejścia do interpretacji $w$ archeologii. Poznań: Obserwator.

Holtorf C.

2009 On the possibility of time travel. Lund Archaeological Review, 15, s. 31-41.

Jarosz K.

2011 Komercjalizacja nauki i mechanizmy podnoszenia atrakcyjności artykułów popularnonaukowych. Zeszyty Prasoznawcze, 54(3-4), s. 71-81.

Jarosz K.

2012 Who's to blame for the tabloidization of archaeology or how to sell science cheap in the Polish press. W: R. Chowaniec, W. Więckowski (red.), Archaeological heritage: methods of education and popularization (BAR International Series 2443, s. 97-100). Oxford: Archaeopress.

Jasiewicz K., Olędzki Ł.

2005 Od nostalgii do fascynacji - doświadczanie przeszłości. W: J. Grad, H. Mamzer (red.), Kultura przyjemności. Rozważania kulturoznawcze (s. 183-208). Poznań: Wydawnictwo Naukowe UAM. 
Johnson M.

2013 Teoria archeologii. Wprowadzenie. Kraków: Wydawnictwo Uniwersytetu Jagiellońskiego.

Jones S.

2009 Experiencing authenticity at heritage sites: some implications for heritage management and conservation. Conservation and Management of Heritage Sites, 11(2), s. 133-147.

Kantor R.

2010 Zabawa przeszłością - zabawa w przeszłość. Historia uludyczniona. Annales Universitatis Paedagogicae Cracoviensis. Studia Sociologica, 3, s. 134-149.

Kobyliński Z.

2001 Teoretyczne podstawy konserwacji dziedzictwa archeologicznego. Warszawa: Fundacja Res Publica Multiethnica, IAiE PAN.

Kokowski A.

2011 Archeologia naprawdę żywa. W: M. Ausz, G. Miliszkiewicz, H. Stachyra, D. Szewczuk (red.), Muzea skansenowskie we współczesnej edukacji historycznej (s. 13-24). Lublin: Polskie Towarzystwo Historyczne.

Kwiatkowski P.T.

2008 Pamięć zbiorowa społeczeństwa polskiego $w$ okresie transformacji. Warszawa: Wydawnictwo Naukowe Scholar.

Kwiatkowski P.T.

2009 Czy lata III Rzeczypospolitej były „czasem pamięci”. W: A. Szpociński (red.), Pamięć zbiorowa jako czynnik integracji i źródto konfliktów (s. 125-166). Warszawa: Wydawnictwo Naukowe Scholar.

Kwiek J.

2007 Dziecko w przestrzeni teatralizowanej reklamy komercyjnej. M. Karasińska, G. Leszczyński (red.), Dziecko i teatr w przestrzeni kultury, t. 1: Teatr w świecie (s. 72-84). Poznań: Centrum Sztuki Dziecka w Poznaniu.

Lowenthal D.

1985 The past is a foreign country. Cambridge: Cambridge University Press.

Lowenthal D.

2002 The past as a theme park. W: T. Yung, R. Rile (red.), Theme park landscapes: antecedents and variations (s. 11-23).Washington D.C.: Dumbarton Oaks Research Library and Collection.

Mamzer H.

1998 Archeologia jako uobecnianie przeszłości. W: W. Wrzosek (red.), Świat historii (s. 299-307). Poznań: Instytut Historii UAM.

Mamzer H.

2004 Archeologia $i$ dyskurs. Rozważania metaarcheologiczne. Poznań: Instytut Archeologii i Etnologii PAN.

Mamzer H.

2008 Estetyzacja archeologii. W: B. Gediga, W. Piotrowski (red.), Sztuka pradziejowa i wczesnohistoryczna jako źródto historyczne (s. 63-83). Biskupin-Wrocław: Muzeum Archeologiczne, PAN o/Wrocław.

Mamzer H.

2011 O archeologicznej autokreacji. W: D. Minta-Tworzowska, A. Marciniak, M. Pawleta (red.), Współczesne oblicza przeszłości (s. 25-38). Poznań: Wydawnictwo Poznańskie.

Marciniak A.

2009 Poznawanie i przedstawianie przeszłości - dylematy współczesnej archeologii pradziejowej. W: Ł. Grützmacher (red.), Narracja, historia, fikcja. Dawne kultury w historiografii i literaturze (s. 229-237). Warszawa: Wydawnictwo Trio. 
Marciniak A.

2012 Przedstawianie i narratywizm w archeologii. W: S. Tabaczyński, A. Marciniak, D. Cyngot, A. Zalewska (red.), Przeszłość społeczna. Próba konceptualizacji (s. 162-177). Poznań: Wydawnictwo Poznańskie.

Marciniak A.

2013 O przeszłości. Dylematy przedstawiania w archeologii. Rocznik Antropologii Historii III, 1(4), s. 17-54.

Marciniak A., Minta-Tworzowska D., Pawleta M. (red.)

2011 Wspótczesne oblicza przeszłości. Poznań: Wydawnictwo Poznańskie.

Matela L.

2006 Tajemnice Stowian. Poznaj sekrety słowiańskich przodków. Białystok: Studio Astro-

Merriman N. (red.) psychologii.

2004 Public archaeology. London-New York: Routledge.

Minta-Tworzowska D.

2009 Do kogo „należy” przeszłość Biskupina? Przegląd Archeologiczny, 57, s. 7-22.

Minta-Tworzowska D.

2012 Źródło / ślad / artefakt / rzecz/ przedmiot. W: S. Tabaczyński, A. Marciniak, D. Cyngot, A. Zalewska (red.), Przeszłość społeczna. Próba konceptualizacji (s. 137-161). Poznań: Wydawnictwo Poznańskie.

Nieroba E., Czerner A., Szczepański M.S.

2009 Między nostalgią a nadzieją. Dziedzictwo kulturowe jako dyskursywny obszar rzeczywistości społecznej. W: E. Nieroba, A. Czerner, M.S. Szczepański (red.), Między nostalgia a nadzieją. Dziedzictwo kulturowe w ujęciu interdyscyplinarnym (s. 17-36). Opole: Wydawnictwo Uniwersytetu Opolskiego.

Nieroba E., Czerner A., Szczepański M.S.

2010 Flirty tradycji z popkultura. Dziedzictwo kulturowe w późnej nowoczesności. Warszawa, Wydawnictwo Naukowe Scholar.

Nora P.

2010 Czas pamięci. Respublica Nowa, 10(2010), s. 142-151.

Paardekooper R.

2012 The value of an archaeological open-air museum is in its use. Understanding archaeological open-air museums and their visitors. Leiden: Sidestone Press.

Pawleta M.

2010 Encounters with the past: the significance of archaeological festivals in contemporary Poland. W: A. Arnberg, T. Stjärna (red.), Communicate the past ways to present archaeology to the public (s. 57-76). Västerås: Stiftelsen Kulturmiljövärd Mälardalen.

Pawleta M.

2011a „Przemysł przeszłość”: wybrane aspekty komercjalizacji przeszłości i produktów wiedzy archeologicznej we współczesnej Polsce. Sprawozdania Archeologiczne, 63, s. 9-54.

Pawleta M.

2011b Przeszłość jako źródło przyjemności. Przegląd Archeologiczny, 59, s. 1-28.

Pawleta M.

2011c Odległa przeszłość w życiu współczesnego człowieka. Przypadek góry Ślęży. W:

A. Marciniak, D. Minta-Tworzowska, M. Pawleta (red.), Wspótczesne oblicza przeszłości (s. 231-252). Poznań: Wydawnictwo Poznańskie.

Pearson M., Shanks M.

2001 Theatre/archaeology. London-New York: Routledge. 
Peterssoni B., Narmo L.E. (red.)

2011 Experimental archaeology. Between enlightenment and experience. Lund: Lund University.

Radtchenko D.

2006 Simulating the past: reenactment and the quest for truth in Russia. Rethinking History, 10(1), s. $127-148$.

Ritzer G.

2004 Magiczny świat konsumpcji. Warszawa: Warszawskie Wydawnictwo Literackie Muza.

Rowan Y., Baram U. (red.)

2004 Marketing heritage: archaeology and the consumption of the past. Walnut Creek: Left Coast Press.

Schadla-Hall T.

1999 Editorial: public archaeology. European Journal of Archaeology, 2(2), s. 147-158.

Schadla-Hall T.

2006 Public archaeology in the twenty-first century. W: R. Layton, S. Shennan, P. Stone (red.),

Selwyn T.

A future for archaeology. The past in the present (s. 75-82). London: UCL Press.

1996 Introduction. W: T. Selwyn (red.), The tourist image: myths and mythmaking in tourism (s. 1-32). Chichester: Wiley.

Siemiński T.

2004 Kamienne kręgi w Węsiorach - potoczna świadomość prehistorycznego zabytku. Koszalińskie Zeszyty Muzealne, 24, s. 173-181.

Skeates R., McDavid C., Carman J. (red.)

2012 The Oxford handbook of public archaeology. Oxford: Oxford University Press.

Skitek J.

2012 Percepcja krajobrazu kulturowego w reinterpretacjach New Age na przykładzie kamiennych kręgów w Węsiorach. W: K. Kajda, D. Kobiałka (red.), Myśl-percepcja i ekspresja (s. 187-212). Poznań: Koło Naukowe Studentów Archeologii.

Skórzyńska I.

2010 Widowiska przeszłości. Alternatywne polityki pamięci 1989-2009. Poznań: Instytut Historii UAM.

Sommer U.

1999 Slavonic archaeology: Groß Raden, an open air museum in a unified Germany. W:

P. Stone, P.G. Planel (red.), The constructed past: experimental archaeology, education, and the public (s. 157-170). London-New York: Routledge.

Szacka B.

2009 Zmiany stosunku do przeszłości po przeobrażeniach ustrojowych 1989 roku w Polsce. Przegląd Filozoficzno-Literacki, 4(25), s. 415-427.

Szpociński A.

2005 Autentyczność przeszłości jako problem kultury współczesnej. W: A. Szpociński (red.), Wobec przeszłości. Pamięć i przeszłość jako elementy kultury wspótczesnej (s. 292-302). Warszawa: Instytut im. Adama Mickiewicza.

Szpociński A.

2007 O współczesnej kulturze historycznej Polaków. W: B. Korzeniewski (red.), Przemiany pamięci spolecznej a teoria kultury (s. 25-43). Poznań: Instytut Zachodni.

Szpociński A.

2010 Współczesna kultura historyczna. Kultura Wspótczesna, 1(63), s. 9-17. 
Szpociński A.

2012 Widowiska przeszłości. Pamięć jako wydarzenie. W: E. Hałas (red.), Kultura jako pamięć. Posttradycjonalne znaczenie przeszłości (s. 63-75). Kraków: Zakład Wydawniczy NOMOS.

Tabaczyński S.

1987 Archeologia średniowieczna: problemy, źródła, metody, cele badawcze. Warszawa: Ossolineum.

Tarkowska E.

2012 Pamięć w kulturze teraźniejszości. W: E. Hałas (red.), Kultura jako pamięć. Posttradycjonalne znaczenie przeszłości (s. 17-42). Kraków: Zakład Wydawniczy NOMOS.

Trzciński M.

2010 Rekonstrukcje archeologiczne a rzeczywistość. W: J. Wrzesiński, A.M. Wyrwa (red.), Przeszłość dla przyszłości. Problemy edukacji muzealnej. Materialy Konferencji z okazji Jubileuszu 40-lecia Muzeum Pierwszych Piastów na Lednicy, Lednica 11-13 września 2009 r. (s. 87-92). Lednica: Muzeum Pierwszych Piastów na Lednicy.

Walenta K.

2006 Kręgi kamienne z okresu rzymskiego na Pomorzu. Legendy i rzeczywistość. W: A. Stępień-Kuczyńska, M. Olędzki (red.), „Cultura et politica”. Studia i rozprawy dedykowane Profesorowi Jerzemu Kmiecińskiemu (s. 85-93). Łódź: Wydawnictwo Uniwersytetu Łódzkiego.

Wieczorkiewicz A.

2008 Apetyt turysty. O doświadczaniu świata w podróży. Kraków: Universitas.

Woźniak M.

2010 Przeszłość jako przedmiot konstrukcji. O roli wyobraźni w badaniach historycznych.

Lublin: Wydawnictwo UMCS.

Zalewska A.

2011 Społeczne wytwarzanie przeszłości. Archeologia materii reaktywowanej. Sensus Historiae. Studia Interdyscyplinarne, 2, s. 63-80.

Zalewska A.

2014 Prospołeczna, partycypacyjna i „wspólnotowa” archeologia bliskiej przeszłości jako sposób na nadawanie sensu trwaniu (ludzi i rzeczy) oraz jako antidotum na niedostatki wiedzy i trywializację przeszłości. Studia Humanistyczne AGH, 13(2), s. 19-39.

Ziębińska-Witek A.

2011 Historia w muzeach. Studium ekspozycji Holokaustu. Lublin: Wydawnictwo UMCS.

\section{SELECTED ASPECTS OF SOCIAL FUNCTIONING OF PRODUCTS OF ARCHAEOLOGICAL KNOWLEDGE AND ARCHAEOLOGY IN PRESENT \\ DAY POLAND}

\section{Su m mary}

The article aims to present forms and methods of social functioning of the products of archaeological knowledge, and indirectly also archaeology as a discipline investigating the distant past, in present-day Poland. These aspects belong to the research area referred to as "public archaeolo- 
gy". For the purpose of this article, the term is used in its broad sense: it refers to the methods of presenting the achievements of archaeology to a society, ways of interpreting the past, as well as the activities targeted towards public understanding of the works undertaken by archaeologists and involving wider public into them. One of the tasks of such understood public archaeology is to determine the relationship between archaeology and society, therefore social obligations of archaeology and its role in the contemporary world.

The article aims to formulate certain regularities seen in the processes of manifesting prehistoric past in modern times, certain developmental trends in this respect and the relationship between the two. The author assumes that the analysis of the phenomenon of the manifestation of the archaeologically created past in the contemporary world would be impossible without referring to the wider cultural context, so the article describes the basic strategies of the manifestation of archaeological past. The trends shaping them, namely sensational attitude towards archaeological discoveries, reconstructionism, theatralisation of the past and its festivalisation are referred to. The article also discusses the characteristic elements of the aforementioned trends: democratisation of the attitude towards the past; human's need for direct contact with the past or its reconstructions/reenactments and sensuous forms of experiencing the past; the question of authenticity in contact with the past; commercialisation of the past; its aestheticisation, as well as the past as a ludic phenomenon - as a source of pleasure and entertainment, and also the issue of learning about the past by means of playing. These elements create a specific approach of the modern man towards the past, including this prehistoric.

Conceptualisation of the presence and functioning of the products of archaeological knowledge in the social context is a field rarely explored in Polish archaeology, but, in the author's opinion, having the considerable potential for development of that discipline. The author also claims that the issues relating to the functioning of the products of archaeological knowledge in the social space, comprise potentially inspiring challenge to the theory and practice of archaeology, not only in Polish, but also in the world's context, in the twenty-first century. They provide new perspectives to look at the subject of archaeological research and views of the past created by it.

Translated by Lucyna Leśniak 